\title{
WORLD ENGLISHES FROM A HOLISTIC VIEW AND CONSIDERATIONS ON ENGLISH EDUCATION IN VIETNAM
}

\author{
Tran Thi Hao ${ }^{1}$, Ngo Dinh Phuong ${ }^{2, *}$ \\ ${ }^{1}$ PhD Candidate, Griffith University, Australia \\ ${ }^{2}$ Vinh University, 182 Le Duan, Vinh, Nghe An, Vietnam \\ Received 05 April 2017 \\ Revised 08 November 2017; Accepted 28 November 2017
}

\begin{abstract}
The development of English as the mutual language among ASEAN since 2008 and the formation of ASEAN Economic Community since 2015 have set milestones in the social and educational development of each country in this organisation. In English education in Vietnam, understanding the diversity of Englishes in the organisation has become an important task. This article aims to present a holistic view of World Englishes (WE) in research generally and in relation to English education in Vietnam particularly by illustrating the Vietnamese English teachers' perceptions of WE in the Vietnamese teaching context. The data were collected via an online questionnaire using a snowball sampling method from seventy-six respondents who are English lecturers from twenty-six universities or colleges in Vietnam. The data were also collected from focus group interviews with five participants who were doing Master Degree in Applied Linguistics at an Australian university. The article delineates the findings of the Vietnamese English teachers' perceptions towards WE and their experiences in introducing WE in their teaching context. Discussion of English education in Vietnam, including issues in English teaching, English teachers' development and considerations of the policy context, is also be presented.
\end{abstract}

Keywords: World Englishes, English education, English teachers, Vietnam

\section{Introduction}

Understanding varieties of English, or World Englishes (WE), is considered a crucial task in language teaching and learning to prepare English users for effective and intelligible communication (Brutt-Griffler, 2002; Canagarajah, 2006; Ton \& Pham, 2010). Specifically, the adoption of English as a medium for communication among ASEAN members in 2008 (Kirkpatrick, 2008) and the formation of ASEAN Economic Community in 2015 are milestones in the social and educational development of each member country. Communication in English is thus not just among Vietnamese with other English native speakers but also among other nationalities within the

\footnotetext{
${ }^{*}$ Corresponding author. Tel.: 84-913327040

Email: phuongnd@vinhuni.edu.vn
}

region and ASEAN. Therefore, understanding of Englishes from other countries is important in line with the recognition of certain variants of English in the organisation such as Singaporean English or Cambodian English. This article thus aims to present a holistic view of WE in research generally and in the context of Vietnam particularly in relation to English education by illustrating the Vietnamese English teachers' perceptions of WE in the Vietnamese teaching context. Discussion of English education in Vietnam including issues in English teaching, English teachers' development and considerations of relating policies is presented at the end of the article.

\section{Discussions on WE}

In this article, WE is discussed with respect to its development through the past 
three decades, combined with a review of studies conducted in this field in ASEAN context and Vietnamese contexts.

\subsection{Development of WE}

The term "World Englishes" is defined variably with a range of meanings and interpretations (Bolton, 2004). According to Bolton (2004), the three most common interpretations of WE include an umbrella label of all English varieties, new Englishes (such as Englishes in the Caribbean or Asian Englishes) and the Kachruvian pluricentric approach with three concentric circles, the norm-providing varieties of the inner circle, the norm-developing varieties of the outer circle and the norm-dependent varieties of the expanding circle (see Figure 1). In accordance with the aim of the study which attempts to explore Vietnamese English teachers' perceptions of English varieties in general, within this study the term WE is employed as the first interpretation, which presents an umbrella label covering all varieties of English worldwide.

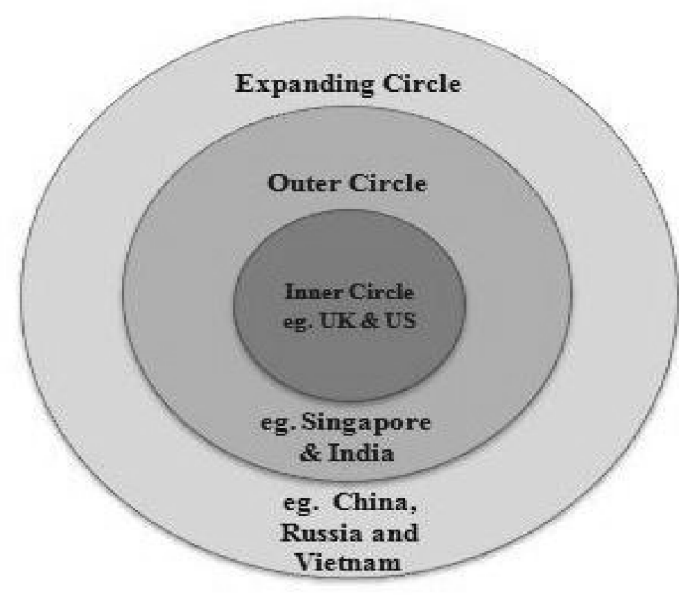

Figure 1. Kachru's 1988 three concentric circles of English varieties

WE has been in the focal discussion in much research. Understanding English varieties other than native-speaker norms has been regarded as necessary for effective communication in contexts where English is used as a lingua franca. Numerous academic articles as well as a number of book-length studies on WE have been widely published in international academic journals such as Asian Englishes, English Today, English WorldWide, and World Englishes. Throughout the 1980 s, in various branches of linguistics research and publications, WE has brought a paradigm shift in English studies. WE has shown important relations with other language studies. In terms of language variation, WE emphasises the pluricentric view of English study or the diversity of English varieties. "Englishes" also symbolises the functional and formal variation in the language and its international acculturation.

The WE paradigm that has brought together varieties of Englishes (Bolton, 2005) has been widely recognised in the past three decades. Kachru (1988) argues that WE makes three basic claims: 1) there exists a repertoire of models for English, not just the native speaker varieties; 2) localised innovations in English which have their pragmatic bases deserve recognition; and 3) the ownership of English lies with all those who use it. WE has recently been interpreted with more comprehensive characterisation with seven characteristics including diversity, plurality, equality, functionality, inclusivity, appropriateness and variability (Proshina, 2012). In Hamid, Zhu and Baldauf (2014), it is argued that the global spread of English has generated "multiple norms at the local, national and regional levels" in response to socio-cultural and pragmatic needs of speech communities (p. 77). These non-native speaker norms are suggested to be equal to native speaker norms and should serve as criteria in judging the appropriateness of English use in Outer Circle contexts (Kachru, 1988). The exploration of these norms as well as teachers' perceptions towards these are thus important in English teaching. 


\subsection{WE and the benefits of revisiting the field} and researching teachers' perceptions of WE

Firstly, the importance of understanding the teachers' perceptions of WE or varieties of English is in parallel with the rapid increase in the number of non-native English speakers and communication among non-native speaker communities. Honna (1999) points out that non-native speakers overwhelmingly outnumber native speakers of English. Prodromou (1997) estimated that up to $80 \%$ of communication in English takes place between non-native speakers. For example, the use of English by Indonesian learners is to communicate with Thais, Koreans, Vietnamese, or Japanese. Developing proficiency in communicating with innercircle communities or focusing on only American or British English is not enough for effective and efficient communication. As a result, understanding English varieties and exploring the perceptions of English teachers towards English varieties is an important task.

Secondly, teachers have been posited to have important influences on their students' attitudes and perceptions of language use (Crismore et al., 1996). In otherwords, teachers should equip themselves with an understanding of English issues, in particular WE, to build students' appropriate understanding and attitudes to the importance of WE in English learning and in communication. Exploring teachers' perceptions of WE is thus important for further implications in English teaching and teacher education. Moreover, exploring teachers' perceptions of English varieties is in accordance with Vietnamese English teachers' identity as non-native speakers versus "native-speakerist" elements and native-speaker model (Holliday, 2005). In English teaching in Vietnam, native-speakers still have priority over non-native speakers. This choice of a native speaker model, which is seen as unattainable by students, can also disadvantage the great majority of students (Cook, 2002). For example, Vietnamese students taking part in the study by Tananuraksakul (2009) revealed their shock when encountering WE and communicating with people from different cultures. Therefore, instead of conforming to a native-speaker model in English teaching with the focus on British and American English in Vietnam, it is important that the perceptions of English teachers towards English varieties (especially non-native varieties) are explored for their influences on teaching practices.

Thirdly, the necessity of researching teachers' perceptions of WE or English varieties is illustrated through the change in teaching and learning policy, the requirements of globalisation and transnational education, and the roles of Vietnam in the regional integration process. First, communication among non-native English learners has led to changes in the policy of teaching and learning. In their book on WE, Melchers and Shaw (2011) posit that although universities and schools used to demand just one innercircle variety as standard, they are "now increasingly allowing mixed varieties and focusing on communicative value rather than any particular native usage" (p. 203). Thus, exploring the perceptions of English teachers in Vietnam is a necessity of the factual demands in language use and an appropriate process along with other countries or academic institutions.

Additionally, exploring teachers' perceptions of WE or English varieties parallels with globalisation in education or the trend of transnational education. Along with globalisation and transnational education, the number of Vietnamese students studying abroad is increasing. For instance, within the region, Singapore is among the top five attractive destinations with nearly 10,000 Vietnamese students in 2010. Meanwhile, 
different varieties of Englishes especially Singaporean English (Kirkpatrick \& Bhatt, 2010) or even the mixed code of Singlish has been treated as expressing the local values of Singaporeans in general. Exploring the perceptions and understanding of WE or English varieties such as Singaporean English is thus a vital task in English teaching along with transnational education in globalisation.

Furthermore, researching teachers' perceptions of English varieties or WE is in line with social demands in regional integration process such as integration of Vietnam into ASEAN since 1995. The role of English in ASEAN as a working language since 2007 (Kirkpatrick, 2008) and the current ASEAN Economic Community indicates the necessity of English language teaching curriculum to provide students with varieties of Englishes or cultures of the people they are communicating with. Additionally, along with the recognition of WE or new English varieties in other neighbor countries namely Malaysia (Chan \& Wong, 2002), Singapore (Ho \& Wong, 2001) or Brunei (O'Hara-Davies, 2010), it is now evident that understanding only Standard English is not sufficient for successful communication. Rather, it is necessary to understand the recognised Englishes from these regional countries for more effective communication purposes. In short, how the teachers perceive World Englishes and its incorporation into their teaching is an important task to be explored.

\subsection{Previous studies in Asian context}

In line with the importance of varieties of Englishes in English teaching and learning, much research has been done in Asia to explore the perceptions of English teachers. In some Asian contexts, such as India and Pakistan, new Englishes are widely recognised while in others, such as Japan, where English is mainly used as a foreign language, the awareness and acceptance of WE are lower. Suzuki (2011) investigated three Japanese student teachers' understanding of the diversity in English and their perspectives on introducing WE into English language teaching in Japan. Individual interviews along with student writing were explored in the study. Participants in the study displayed different levels of knowledge about varieties of English, which Suzuki attributed to their prior experiences of social and educational interaction with other second language speakers of English. Nonetheless, only American and British English were regarded as appropriate for English language teaching. The study recommended developing teachers' perceptions of other varieties of English in teacher preparation programs as well as developing skills in teaching English as an international language.

Tsui and Bunton (2000) scrutinised the attitudes of Hong Kong's English language teachers in terms of their discourse and their views on correctness or acceptability of Hong Kong English. Over a thousand electronic messages on language issues of English teachers in Hong Kong through a computer network - TeleNex - over a period of two years were analysed. The results showed a preference among Hong Kong's English teachers for Standard English in formal communication rather than Hong Kong English. Nevertheless, the study predicted the change in societal attitudes towards the local variety of English in Hong Kong and towards varieties of Englishes in general given rapid globalisation and the immense impact of the Internet on communication amongst nations.

Among several studies in ASEAN contexts, Moore and Bounchan (2010) examined Cambodian English by employing questionnaires and focus group interviews. The study investigated the perceptions of teachers, administrators, and students as to the status of Cambodian English, and their preferences for different kinds of English. 
The recognition of Cambodian English was emphasised in the study in line with the perception of English as a second language or an international language rather than a foreign language or lingua franca. Although one particular Standard English variety was preferred in classroom teaching, others were also drawn on as the context dictated. Moore and Bounchan concluded that a balance was needed between teaching Standard English and newer varieties.

Despite the increasing importance of WE in English teaching, very few studies have been conducted in Vietnam to explore the kinds of English used or the perceptions of English teachers towards WE. In line with the recognition of WE among many countries within the ASEAN region, it has been argued that Vietnam should develop an understanding of WE to develop and promote "mutual intelligibility" (Kirkpatrick, 2007, p. 193). Nonetheless, the current trend in English language teaching in Vietnam is to privilege British and American Standard English. Of the few studies that exist discussing WE or issues of different Englishes in the context of Vietnam, Ton and Pham (2010) is directly related to the present study. With the participation of 250 students and 80 university teachers from two universities in Vietnam, the study investigated attitudes towards the preferred kinds of English via a mixedmethod approach involving questionnaires and interviews. The study found that although students used English more often with nonnative speakers, they still preferred studying British and American English. Ton and Pham also suggested that students should explore more English varieties outside the classroom for more effective communication with nonnative speakers. The study is presented in the next section will focus on a broader context of Vietnam with more and deeper insights from the teachers' perceptions of WE.

\section{The study and findings}

In light of the importance of WE in English education, especially the necessity of exploring English teachers' perceptions towards WE in the Vietnamese teaching context, the study aims to answer the following question: What are the perceptions of Vietnamese English teachers towards WE and incorporating WE in their English teaching contexts? Tertiary level was chosen for the study, due to the reason that among Vietnam teaching contexts, university teachers have more autonomy than teachers at other levels in the choice of teaching materials and teaching content. Additionally, their students may have stronger language proficiency and more experience of other kinds of English through overseas studies or workplace requirements. Therefore, at this stage, the exploration of teachers' perceptions at this level is more valuable than other levels.

The data were collected from the first author's Master thesis at one university in Australia over six weeks. A mixed-methods approach (involving both quantitative and qualitative data) with the focus on qualitative data was employed to answer the research question. Seventy-six Vietnamese English teachers at the university/college level in Vietnam took part in the first stage of the research conducted using an online questionnaire (see Table 1). Five of the participants, who were Vietnamese English teachers and pursued a master's degree in Applied Linguistics at an Australian university (see Table 2), participated in the interview stage, including individual semi-structured interviews and a focus group interview, after they had answered the online questionnaire. These were all administered in English for the reason that the participants are all Vietnamese English lecturers at university and college level with good English proficiency. English was also chosen for both data collection and data analysis to avoid gaps, misunderstanding 
or difficulties when translating technical terms from English into Vietnamese. The use of English in interviews is thus useful for the participants to express their ideas, although the code-switching is not prohibited.

In analyzing the data, the first author classified the participants into subgroups according to their teaching major and their previous experiences of WE. Quantitative data were analysed for trends and variance by providing frequencies and percentages. Qualitative data were the major focus of the data analysis. Data from open questions on the online survey, as well as from individual and focus group interviews were firstly transcribed and then analysed and interpreted through four stages: reading, coding, sorting, and interpreting. Excerpts from the interview data in the following section are presented in participants' own words, including any nonstandard forms and expressions.

In this article, the main findings from the two stages of the study including the online survey and the individual interviews and focus group discussion are presented to grasp a holistic view of the Vietnamese English teachers' perceptions towards WE and introducing WE into their teaching.

\subsection{Online survey}

This section presents findings from online survey which was designed with both closed questions and open questions. Table 1 provides the general description of the participants based on the findings of closed questions about demographic data.
As for the question exploring the variety of English currently widely used in English teaching in Vietnam, $89 \%$ of the respondents presented American and British English. Given that the answer "Others" constituted $12 \%$, it was clarified by the interviewees as "both American and British English". Although the superiority of native varieties such as American or British English was emphasised, non-native varieties such as Hong Kong English and ASEAN English varieties (i.e. Singaporean English) were also recognised by the respondents along with their acceptability of Vietnamese English.

Vietnamese English was widely reported in the survey by the participants as an acceptable term along with its features in terms of pronunciation, grammar, and culture, which were noted in reference to differences between Vietnamese and English. Word order ("house big," not "big house") and the use of articles or plural features ("two book," not "two books") were noted by participants as features of Vietnamese English. This will be further discussed in the discussion section about their acceptability. In addition, Vietnamese cultural norms involving direct questions of a personal nature (e.g., related to age, marital status, or financial status) were included as Vietnamese English features, which is to some extent similar to the results of Srihar (1991) regarding request strategies of Indian English transferred from local languages (as cited in Kirkpatrick, 2007).

Table 1. General description of participants in online questionnaire

\begin{tabular}{|c|c|c|c|c|c|c|c|c|}
\hline $\begin{array}{c}\text { Number of } \\
\text { participants }\end{array}$ & \multicolumn{2}{|c|}{ Gender } & \multicolumn{5}{c|}{ Age range } & $\begin{array}{c}\text { Total } \\
\text { number of } \\
\text { universities/ } \\
\text { colleges }\end{array}$ \\
\hline \multirow{2}{*}{$\mathrm{N}=76$} & Female & Male & Under 25 & $26-30$ & $31-35$ & $36-40$ & Above 40 & \\
\cline { 2 - 8 } & $\begin{array}{c}56 \\
(73.7 \%)\end{array}$ & $\begin{array}{c}20 \\
(26.3 \%)\end{array}$ & $\begin{array}{c}2 \\
(2.6 \%)\end{array}$ & $\begin{array}{c}34 \\
(44.7 \%)\end{array}$ & $\begin{array}{c}24 \\
(31.6 \%)\end{array}$ & $\begin{array}{c}5 \\
(6.5 \%)\end{array}$ & $\begin{array}{c}11 \\
(14.5 \%)\end{array}$ & \\
\hline
\end{tabular}


Native and non-native Englishes were perceived by participants as having different roles and positions in English teaching in Vietnam. Native Englishes were explained as the kinds currently used in course books or English teaching materials used in English courses in Vietnam. These materials include English-language media such as films or game shows which extensively influence daily life in Vietnam. Importantly, international tests, namely IELTS, TOEFL, and TOEIC, were regarded by the participants as an important goal for Vietnamese students. Notably, all these tests currently privilege native varieties of English. The importance of non-native kinds of English was also noted by many teachers in the study. Similarly, non-native varieties were claimed by the participants to contribute to successful communication, which focuses more on fluency than accuracy.

Introducing English varieties in English teaching in Vietnam was also pointed out in the survey with both benefits and challenges although it was widely regarded as an important task in English teaching by the participating teachers. Three main benefits of introducing English varieties were shown from the responses. Firstly, it was noted that introducing WE can prepare students for real-life encounters with different varieties of English. It was emphasised by one teacher that "students will be well-prepared for real-life encounters with varieties of English". This was in accordance with another opinion that it helps learners to "expose and get familiar with different varieties of English that are used currently in communication outside classroom". Secondly, introducing English varieties is also considered a beneficial factor for successful communication. One respondent emphasised that "They [the students] are better at communicating with people from different countries and areas in English...". Another respondent presented the same idea, "Students are familiar with different varieties of English. They can communicate better". Thirdly, confidence and awareness of students and English learners and users were stated as the benefit of introducing English varieties. It was posited, "They [the students] are more confident in using their own English which is not really standard", or "my Vietnamese students can feel more self-confident when they speak English even though they are not native speakers". Their attitudes towards the influences of native speakers or native varieties in English teaching and learning thus can be changed.

Teaching materials, time and effort consuming as well as students' reluctance, resistance and confusion were commonly identified by the respondents in the survey as the challenges of introducing English varieties. Firstly, the teachers claimed that teaching materials are a big problem because "there might be insufficient materials for introducing varieties of English for students", or "lack of proper teaching materials". Secondly, time- and effort-consuming in class was also shown as one issue that needs to be taken into consideration when introducing English varieties. One respondent said that "they [the teachers] have no extra time for introducing these varieties". Teachers' awareness and knowledge of WE or English varieties are also other constraints to Vietnamese English teachers in terms of introducing English varieties. They presented that "The teachers themselves do not know well about the varieties". Importantly, regarding students' perspectives, the teachers noted that their students might show their reluctance and confusion when being introduced to these varieties. They stated, "They [English varieties] can make students confused". Another respondent also said that "students 
may feel bored with those non-native Englishes. They just want to listen to native speaker voices only".

The next section presents main findings from individual interviews and group discussions among the focus-group participants.

\subsection{Individual interviews and group discussion}

Further insights of the Vietnamese English teachers' perceptions towards WE and introducing WE into diverse specific teaching contexts were highlighted through individual interviews and a group discussion among the five interviewees as described in Table 2. later when they are exposing with other varieties of English". Manh highlighted the importance of introducing English varieties by mentioning the case of his University as one example. With the aim to reduce students' communication breakdown, a course relating to WE or English varieties is conducted in his university.

However, various difficulties in divergent teaching contexts were presented when the interviewees mentioned the challenges of introducing English varieties. Of those, teaching and learning materials, time and effort consuming, the selection of suitable varieties, and students and parents' resistant

Table 2. General description of interviewees

\begin{tabular}{cccccc}
\hline $\begin{array}{c}\text { Name } \\
\text { (pseudonyms })\end{array}$ & Gender & Age & City in Vietnam & English teaching major & $\begin{array}{c}\text { Semester in } \\
\text { university }\end{array}$ \\
\hline Manh & Male & 26 & Hanoi & Major students & 2nd semester \\
Thanh & Female & 25 & Hue & Major students & 3rd semester \\
Suong & Female & 26 & Hanoi & $\begin{array}{c}\text { Major students } \\
\text { Both major and non- } \\
\text { major students }\end{array}$ & 2nd semester \\
Tu & Female & 31 & An Giang & $\begin{array}{c}\text { Both major and non- } \\
\text { major students }\end{array}$ & 2nd semester \\
Linh & Male & 28 & Hanoi & &
\end{tabular}

First of all, all of the interviewees agreed that introducing English varieties is important to English teaching. Linh emphasised the importance of introducing English varieties and the suggestion for English learners to understand many English varieties for future encounters.

"I think it is really important to help the learners understand and as teachers we should introduce students with varieties of English...

English learners should be aware of as many of English varieties as possible".

Suong supported that "The job of teaching is to prepare students for real-life later so if we can prepare them to avoid the shock attitudes were generally stated as common challenges. Manh clearly pointed out several important challenges: "Number 1 as I said, lack of materials, number two, that would be very time and effort consuming, and also another major issue is important is the resistance of part of students...". Linh also pointed out various challenges:

"The first thing is...we have to prepare students to get used to the terminology of WE... and accept this term... And the second thing, to prepare some kind of materials... most of materials... have native-like English.... The third one is... which one of varieties we choose and have superiority..." 
Suong with the experiences of introducing different English varieties into her teaching raised students' resistance or attitude as an important challenge. She showed that the students took that variety as mistake and blamed on this as the reason they could not complete the listening tasks.

The interviewees also presented varying ideas in line with their different teaching contexts when mentioning their opinions towards their colleagues' attitudes. Suong and Manh noted that their colleagues have proper understanding of WE as they do. In contrast, Tu posited that her colleagues, like her, do not have knowledge of WE or English varieties, "I think that my colleagues have just some general information but not very clear or exactly the term like this." Thanh noted that her colleagues are conservative with native varieties or native-like model and "try to correct the students' pronunciation, intonation to become native speakers.."; meanwhile, she is more open and focused on more communication and fluency in her teaching. Obviously, there existed certain gaps and differences in the interviewees' understanding of WE particularly and in their teaching contexts generally.

When being asked about suggestions that the interviewees would make to introduce English varieties in their English teaching, they presented different ideas. Students' needs analysis, their awareness and attitudes, teacher education investment, teachers' awareness and attitude, and careful preparation for first encounter were commonly presented. First, students' needs analysis along with their purposes of studying English, their emotional and cultural issues should receive attention. The interviewees presented that it would be necessary to have careful needs analysis, especially students' attitudes and interests beforehand. Suong noted:

"I think need analysis is very important to do here because if we students and teachers both aware of the kinds of English they will use in future, their purposes of learning English or the kinds of English they will encounter later so the attitude may change...."

With a distinct teaching environment from Manh and Suong, Thanh recommended that the change of teachers' attitude and awareness towards English varieties is important. The investment in teacher education, especially teacher study abroad was also emphasised by the interviewees to improve the teachers' knowledge and provide them with opportunities for real communication. Tu suggested the employment of technology and media as the sources of introducing English varieties to get students familiar with these varieties. She noted, "I will use media to let students about more different varieties of English...I think we have to choose one primary English variety to teach English varieties..."

The change of the students' awareness, their students' attitude or resistance to English varieties was also recommended. Manh noted that "Teachers should introduce, inspire students with English varieties because students are still more interested in studying native varieties through add-ons components besides native varieties". He asserted that native-like proficiency should not be the target, but intelligibility and comprehensibility.

Careful preparation for the students' first encounter with different English varieties was also considered an important task. Suong suggested employing teachers' personal experiences as effective example to illustrate the importance of English varieties.

"I think maybe I will tell them a story of how I myself have been shocked and have overcome that kind of initial shock and also remind them to be more open....Preparing students in terms 
of cultural knowledge and emotional

knowledge is very important"."

In the group discussion, when asked to present their opinions towards the statement: "Introducing English varieties, especially nonnative varieties, helps students to be confident with their own English and proud of their own English variety", the interviewees presented different points of view. Manh agreed with this idea and posited that accent is not really important. He emphasised the importance of students' tolerant attitude with different accents, which was also supported by Thanh. She clarified, "In my teaching, I focus on more communication, fluency and a bit on accuracy, the accent needs to be accepted to identify identity...". Linh added the positive prospect that the students' Vietnamese accent and Vietnamese variety of English might be accepted around the world. Despite having rapport on this statement, Suong took more caution with the word "confidence". She showed her hesitance: "...That kind of confidence should be taken with caution. It may mislead students into believing that they do not need improvement..." However, they all showed an appropriate attitude towards English varieties, whether they are native or non-native varieties.

The second statement aims to present a discussion of the issue of native-like competence as the main goal of teaching, which deduces the un-necessity of introducing English varieties into teaching. Manh presented his disagreement by noting that, "native-like is most of the time not the target of learning English but the effectiveness on communication". This was agreed by the other interviewees. Regarding the students' confusion, Linh said that "they might be confused at the first stage", but for him, "that's not important issue". Tu suggested the level of students should be taken into investigation when introducing English varieties to reduce students' confusion.

The third issue related to the examoriented purposes of teaching and learning English in Vietnam, which might lead to an emphasis on teaching British and American English only. Discussing this point, all interviewees emphasised the necessity of an analysis of students' needs to identify the students' purposes of learning English and choose suitable teaching content and method. They also put an emphasis on the necessity of English varieties on real life communication or encounters of different English varieties. They claimed that introducing English varieties does not aim to change the learners' goals or targets (exam-oriented) but their awareness and attitudes towards English varieties. Manh added that "No matter how hard we try, we cannot reach the target (Standard English)". Therefore, he suggested the teachers let the students aim for their targets, but still introduce English varieties to help students better with real-life encounters and communication. "We still focus on those targets, but at the same time, we can change students' awareness, attitude towards remarkable English varieties (through introducing English varieties)...”.

Overall, through individual interviews and a group discussion among the five focused participants, their perceptions of WE as well as detailed suggestions towards introducing WE into their teaching in line with their working conditions were uncovered. The next section will discuss further considerations in relation to English education in Vietnam.

\section{Discussion and consideration}

In this section, discussions on the findings of the study are firstly presented. Subsequently, other issues in relation to WE including English teaching, teacher development and relating policies are presented for the current and future English education in Vietnam.

Firstly, the study supported the findings 
of previous studies with regard to the role of Standard English and the communication purposes in Vietnam context. Supporting the findings of Ton and Pham (2010), native Englishes were commonly believed by the participants to be widely used and to exert strong influence on English teaching and assessment. Likewise, the current study showed that Vietnamese students are more likely to communicate in English with nonnative speakers than native speakers, as noted in Kirkpatrick's (2002).

As the findings delineated in the previous section, with regard to introducing varieties of English, different teaching contexts revealed diverse perceived advantages and challenges. Therefore, to develop a suitable approach to the introduction of these varieties of English, teachers must carefully consider each teaching context to employ appropriate actions in teaching or "clear and consistent learning models" (Swan, 2012, p. 384). In addition, different kinds of English must be introduced carefully, as learners may demonstrate confusion and resistance, or at an appropriate stage, as noted by Sewell (2013). It was also recommended that using workshops or informal presentations based on teachers' personal experiences could help raise students' awareness of this topic and its importance. This was considered as an important step before teachers introduce WE.

It was also posited that once the students were aware of the importance of understanding different English varieties, introducing the varieties must be conducted motivationally, such as through warm-up activities or through engaging media such as YouTube. Introducing different kinds of English through English clubs with students' performance was also suggested as a means of encouraging students to explore WE.

In universities with support for teaching WE, Englishes were recommended to be introduced through task-based language teaching. This approach may afford students the autonomy to select which varieties of English they may want to explore. Tasks related to real-life situations might also intrigue and stimulate students with the exploration and understanding of different kinds of English, as noted by Matsuda (2003). In universities or colleges with no courses relating to WE, these tasks was suggested to be attached to other courses such as intercultural communication or listening subjects. In these certain circumstances, teachers could also use postcards, YouTube videos, or intercultural movies to introduce different Englishes.

Regarding teachers' knowledge and awareness, changing teachers' conservative attitudes towards other Englishes, including non-native varieties, was also regarded as an important task. Holding workshops, teachers' meetings, and discussions about WE were also recommended. In contrast to Matsuda's (2003) suggestions of bringing in speakers of different varieties into classrooms or changing the recruitment process to include more nonnative English teachers, the participants in this study focused more on investment in overseas teacher training such as that provided by the Vietnamese Ministry of Education and Training. Through their experiences overseas with issues related to other kinds of English, participants noted that they believed that overseas training provides English teachers with real-life experiences to improve their awareness of teaching issues in international contexts.

Besides these above discussed points, other aspects need to be taken into consideration in English education in Vietnam. First, there is a need to provide teacher training to improve teachers' knowledge and awareness. English teachers should also have opportunities to involve themselves in real-life English communication via funded short-term or long- 
term overseas courses. Further discussions or workshops should also be held to reach a consensus among teachers regarding the best methods for including WE in specific contexts. A degree of autonomy, for both teachers and learners, is also required so the varieties of English drawn on in the curriculum are most relevant to their current and future needs.

In addition, teaching materials including textbooks and curriculum should be taken into investigation for better teaching and learning outcomes. Teaching materials are important, which influences on the perceptions of English teachers and learners. Therefore, on the one hand, teaching materials should cover the interest and perceptions of English teachers; on the other hand, they should be varied so that teachers and learners can expose to different varieties. From these, students can also choose their own varieties which they aim to explore in details.

Furthermore, the growing recognition of the plurality of English underling WE paradigm has problematised the conventional second language acquisition (SLA) views of errors. If English use in emerging Englishspeaking contexts is to be judged by local norms, as argued by WE scholars, applying exocentric norms in these contexts can be inappropriate (Hamid, 2014). In SLA, deviations from NS norms, which are believed to result from limited linguistic competence, are called errors. However, these may not necessarily be errors in WE, particularly when an idiosyncratic form appears systematic and is shared by a speech community. On the other hand, despite the significant growth of WE, varieties of new Englishes have yet to develop widely acceptable endocentric norms. Though the introduction of WE might be still at an early stage in the English teaching context in Vietnam, in association with the further development of WE, this issue thus must be addressed for further consideration in the light of research of this field.

In the case of Vietnam, the current study showed that WE is still new and teaching WE is still an individual teacher choice. In line with the development of WE in English teaching context in Vietnam, further critical questions will be raised that teachers and educational developers might face, such as the question of how TESOL teachers distinguish between errors in the SLA sense and varietal features in the WE sense (Hamid, 2014). As it is claimed, failure to draw clear boundaries between errors and nurture innovations may have academic and social consequences (Hsu, 2012). In other words, since teachers are already involved in the process of judging English as part of their practice, it is important to investigate the processes and criteria for distinguishing between errors and innovations from their perspectives. As noted in the findings of the study, some teachers still consider negative transfer from the first language learning, Vietnamese, to foreign language learning, English, as the features of Vietnamese English (i.e. "house big", not "big house". Meanwhile, tenses were pointed out as grammatical features of Indonesian English (Kirkpatrick, 2007). These perceptions will probably influence teachers' teaching practices, especially in line with the introduction of World Englishes in their teaching contexts. These issues still remained to be further addressed and answered in the context of English teaching in Vietnam not only at individual teacher level but must be at a larger scope of researching.

In accordance with the perceptions of teachers toward WE in the context of Vietnam, in addition to discussions in the field in relation to errors and norms, the development of English in specialised area such as Journalism or Business English needs to be taken into consideration. It is undeniable 
that English communications among ASEAN countries, especially after the resolutions of the ASEAN Economic Community, is mainly conducted in the field of business. Therefore, how to teach as well as what or which varieties to be included in Business English in line with the development of different Englishes from other countries of the region or just Standard English are unavoidable questions. Indeed, how to equip students with the understanding and exposure to these Englishes should thus be addressed for further consideration by educators.

Combined with these concerns, policy makers and educators should exercise care in finding suitable approaches for teachers' development, teaching materials and testing and assessment tools. Choosing a suitable assessment tool is one of the important tasks that policy makers and educators need to consider. In fact, besides the international tests widely employed in English teaching and learning in Vietnam such as IELTS or TOEFL, the Vietnamese Standardised Test of English Proficiency (VSTEP) has been constructed and put into effect since 2015. One of the aims of this test is to construct an assessment tool which is more appropriate with Vietnamese English users. In terms of listening, for instance, this assessment tool covers different listening topics close to the context of Vietnamese and non-native speakers perspectives. Rather than testing native speaking ability of native accent, it is noted in the training documents of writing test items for VSTEP that the ability to listen to talks or conversations in different accents such as Singaporean English or Indian English were noted as a feature of this assessment tool. However, how to clarify the test aims to teachers and students, or launch and develop more of this kind of test to the public still need more work from the policy makers at all levels.

\section{Conclusion}

The study reported here explored Vietnamese English teachers' perceptions of World Englishes as well as their beliefs regarding its introduction. Perceptions, suggestions, and imagined actions of the study's participants provide insights into the current experience of teachers who work in contexts where the variety of English taught is not necessarily representative of the varieties that students may be exposed to living and working in the ASEAN region. The research also adds to the limited amount of literature on WE in Vietnam, and provides evidence of the potential influence of WE in English language education in a region which is becoming increasingly interconnected, and where competence in different kinds of English is destined to become necessary for successful intercultural communication.

While this study has provided the insights outlined above, the findings are limited in terms of generalisability, as well as the participants chosen. First, the short turnaround time and limited numbers of participants in the study, with a focus on university and college teachers only, restricts its generalisability. In addition, though unique traits of the interview participants (studying in Australia) provided an important perspective on the current and imagined future roles of WE in Vietnam, the voices of other teachers are also needed to provide a more in-depth understanding of the findings from the online survey.

Further research thus needs to be conducted over a longer period to grasp the breadth of views expressed. More work is needed into the analysis of Vietnamese English features to provide researchers, teachers, and learners with a clear understanding of what makes this variety of English unique. Finally, there has been inadequate research on teachers' judgments of L2 use from the SLA-WE contrastive perspectives. Questions need to be 
raised in terms of whether there is a consensus among teachers in their understandings of errors and varietal features; what criteria they use in judging the status of L2 features; and whether these criteria are different from those suggested in the literature.

\section{References}

Brutt-Griffler, J. (2002). World English. A study of its development. Clevedon: Multilingual Matters.

Bolton, K. (2004). World Englishes. In A. Davies \& C. Elder (Eds.), The Handbook of Applied Linguistics (pp. 367-420). Oxford: Blackwell.

Canagarajah, A. S. (2006). Negotiating the local in English as a Lingua Franca. Annual Review of Applied Linguistics, 26, 197-218.

Chan, S. H. \& Wong, B. E. (2002). The Malaysian English language competency dilemma: Recovering lost grounds through MUET. Journal of Pan-Pacific Association of Applied Linguistics, 6(1), 31-42.

Cook, V. J. (2002). Portraits of the L2 user. Clevedon: Multilingual Matters.

Crismore, A., Yeok-Hwa, K., \& Keng-Soon, S. (1996). Attitudes towards English in Malaysia. World Englishes, 15(3), 319-335.

Hamid, O. (2014). World Englishes in international proficiency tests. World Englishes, 33(2), 263-277.

Hamid, O., Zhu, L, \& Baldauf, J.R. (2014). Norms and varieties of English and TESOL teacher agency. Australian Journal of Teacher Education, 39(10), 76-95

Holliday, A, R. (2005). The struggle to teach English as an international language. Oxford: Oxford University Press.

Honna, N. (1999). Ajia wo Tsunagu Eigo [English Unifying Asia]. Tokyo: ALC.

Ho Wah Kam \& Wong, R. (2003). English language teaching in East Asia Today. Singapore: Eastern University Press.

Hsu, H. L. (2012). The impact of world Englishes on language assessment: Rater attitude, rating behavior, and challenges. Unpublished $\mathrm{PhD}$ thesis. Urbana-Champaign: University of Illinois at Urbana-Champaign.

Kachru, Braj B. (1988). Teaching World Englishes. ERIC/CLL News Bulletin, 12(1).1, 3, 4, 8.

Kirkpatrick, A. (2002). ASEAN and Asian cultures and models: Implications for the ELT curriculum and teacher selection. In A. Kirkpatrick (Ed.), Englishes in Asia: Communication, identity, power and education (pp. 213-224). Melbourne, Australia: Language Australia.

Kirkpatrick, A. (2007). World Englishes: Implications for international communication and English language teaching. New York: Cambridge University Press.

Kirkpatrick, A. (2008). English as the official working language of the Association of Southeast Asian Nations (ASEAN): Features and strategies. English Today, 24(2), 27-34. http://dx.doi.org/10.1017/ $\underline{\mathrm{S} 0266078408000175}$

Kirkpatrick, A. \& Bhatt, R. M. (2010). World Englishes. The study of new linguistic varieties. World Englishes, 29(1), 138-141.

Matsuda, A. (2003). Incorporating World Englishes in teaching English as an international language. TESOL Quarterly, 37(4). http://dx.doi.org/10.2307/3588220

Melchers, G. \& Shaw, P. (2003). World Englishes. London: Arnold.

Moore, S. H. \& Bounchan, S. (2010). English in Cambodia: changes and challenges. World Englishes, 29(1), 114-126.

O’Hara-Davies, B. (2010). Brunei English: A developing variety. World Englishes, 29(3), 406-419.

Prodromou, L. 1997. 'Global English and the Octopus'. IATEFL Newsletter, 137, 18-22.

Proshina, Z. G. (2012). Language Revolution behind the curtain. Paper presented at the 18th International Conference of the International Association of World Englishes. The University of Hong Kong, Hong Kong.

Sewell, A. (2013). English as a lingua franca: Ontology and ideology. ELT Journal, 67(1), 3-10. http:// dx.doi.org/10.1093/elt/ccs061

Sridhar, K. K. (1991). Speech Acts in An Indigenised Variety: Sociocultural Values And Language Variation, In Jenny Cheshire ed. English Around the World. Cambridge: Cambridge University Press.

Suzuki, A. (2011). Introducing diversity of English into ELT: Student teachers' responses. ELT Journal, 65(2), 146-153.

Swan, M. (2012). ELF and EFL: Are they really different? Journal of English as a Lingua Franca, 1(2), 379-389. http://dx.doi.org/10.1515/jelf-2012$\underline{0025}$

Tananuraksakul, N. (2009). Unintelligibility : world Englishes shock and repetition shock in an Australian context. Prospect, 24(2), 42-52.

Ton, H. \& Pham, H. (2010). Vietnamese teachers' and students' perceptions of Global English. Language Education in Asia, 1, 48-61.

Tsui, A. B. M. \& Bunton, D. (2000). The discourse and attitudes of English language teachers in Hong Kong. World Englishes, 19(3), 287-303. 


\title{
WORLD ENGLISHES TÙ̉ CÁI NHÌN TỔNG QUAN VÀ VIẸC XEM XÉT CHÚNG TRONG GIẢNG DẠY TIẾNG ANH TẠI VIẸTT NAM
}

\author{
Trần Thị Hảo ${ }^{1}$, Ngô Đình Phương ${ }^{2}$ \\ ${ }^{1} N g h i e ̂ n$ cúu sinh Đại học Griffith, Úc \\ ${ }^{2}$ Đại học Vinh, 182 Lê Duẩn, Vinh, NghệAn, Việt Nam
}

Tóm tắt: Việc lựa chọn tiếng Anh là ngôn ngữ chung của ASEAN từ năm 2008, cùng với sự hình thành cộng đồng kinh tế chung ASEAN vào năm 2015 đã đặt những dấu mốc quan trọng trong sự phát triển kinh tế và giáo dục của mỗi nước thành viên. Đối với giảng dạy tiếng Anh tại Việt Nam, việc am hiểu sự đa dạng của các phiên bản tiếng Anh trong tổ chức này và khu vực được xem là một nhiệm vụ quan trọng. Bài báo trình bày cái nhìn tổng quan về World Englishes (WE) trong nghiên cứu nói chung và trong mối quan hệ với giảng dạy tiếng Anh tại Việt Nam nói riêng, thông qua việc trình bày cách tiếp nhận của giáo viên tiếng Anh đối với WE. Số liệu của bài báo được lấy từ điều tra trực tuyến gồm 76 giảng viên từ 26 trường cao đẳng, đại học tại Việt Nam, cũng như thông qua phỏng vấn và thảo luận nhóm năm giảng viên đang làm thạc sỹ ngôn ngữ học ứng dụng tại một trường đại học ở Úc. Bài báo trình bày những kết quả có được về cách nhìn nhận của giáo viên tiếng Anh ở Việt Nam đối với WE cũng như việc đưa WE vào giảng dạy. Các tác giả cũng thảo luận các vấn đề về giảng dạy tiếng Anh, việc phát triển giáo viên cũng như những xem xét về các chính sách giáo dục liên quan tới tiếng Anh ở Việt Nam.

Tù khóa: World Englishes, giáo dục tiếng Anh, giáo viên tiếng Anh, Việt Nam 